Marcin PIGŁOWSKI

\title{
PASSENGER CARS IN THE RAPEX NOTIFICATIONS
}

In the study presented similarities within 1533 notifications on passenger cars (subcategory of category motor vehicles)in the Rapid Alert System for Dangerous Non-food Products (RAPEX) in 2006-2017. The studies took into account passenger car brands and year, submitting country, origin country, risk type and entity taking measures. The cluster analysis using two-way joining in Statistica 12 was applied. The most frequently the following brands were notified: Renault, Peugeot, Citroën (originated from France) and Mercedes (from Germany). The number of notifications increased from 2006 to 2017. The passenger cars in the RAPEX were most commonly notified by Germany (it related to Mercedes). The most commonly risks, which were notified were injuries and also fire. The measures against to notified cars were usually taken by economic operator (manufacturer, distributor or importer).

\section{INTRODUCTION}

The legal basis for the Rapid Alert System for Dangerous Nonfood Products (RAPEX) is a directive 2001/95/EC on general product safety [2]. The main objective of the RAPEX is to facilitate quick exchange of information trough contact points of 31 European countries (28 European Union countries and Norway, Iceland and Liechtenstein) and the European Commission about dangerous products posing a risk to consumers health and safety. The manufacturer or distributor have to inform this competent national authority if it finds out that one of its products on sale is dangerous [1].

The RAPEX annual reports indicated that the category motor vehicles was in 2014 fourth [3, p. 13], in 2015 third [4, p. 6, 7] and in 2016 second [5, p. 10] product category in terms of number of notifications. However, in 2006-2017 (twelve-year period) in the RAPEX were 2621 notifications on motor vehicles, including 1533 notifications on passenger cars (see also Fig. 1) and also motorcycles (389), vans (200), lorries (61) and buses (45) [1]. The notifications on motor vehicles in the RAPEX were also noticed by Klaschka [6, p. 33] and Pose-Juan [8, p. 11].

The goal of the study was to examine what were the similarities in the RAPEX notifications within particular passenger car brands and year, submitting country, origin country, risk type and entity taking measures.

\section{MATERIALS AND METHODS}

The data came from the RAPEX database from 2006-2017 and comprised 1533 notifications regarding passenger cars (subcategory in the category motor vehicles). The data was collected in pivot tables and covered the following variables: brand and year, submitting country (in database: alert submitted by), origin country (country of origin), risk type and entity taking measures (risk-original). If the notification concerned two or more brands these brands were defined as "(other)". In the case of variable origin country adopted the first country among all the countries listed in notification.

In order to examine similarities in notifications within particular passenger car brands and other variables applied cluster analysis using two-way joining in Statistica 12. The most important similarities were indicated by dark red and brown blocks.

\section{RESULTS AND DISCUSSION}

In Table 1 presented the number of RAPEX notifications on passenger cars in brands in 2006-2017, arranged in descending order. The total number of notifications was 1533 (as mentioned before) and the mean value was 23 .

Tab. 1. Number of RAPEX notifications on passenger cars in brands [1]

\begin{tabular}{|l|r|l|l|l|r|}
\hline Brand & Number & Brand & Number & Brand & Number \\
\hline Renault & 96 & Hyundai & 19 & Rolls-Royce & 4 \\
\hline Mercedes & 94 & Alfa Romeo & 16 & Daihatsu & 3 \\
\hline Peugeot & 89 & Dodge & 16 & SsangYong & 3 \\
\hline Citroën & 77 & Lexus & 16 & Tesla & 3 \\
\hline Toyota & 74 & Śkoda & 16 & Abarth & 2 \\
\hline Nissan & 69 & Chrysler & 15 & Caterham & 2 \\
\hline Ford & 65 & Lancia & 14 & Lamborghini & 2 \\
\hline Volvo & 64 & Maserati & 14 & Range Rover & 2 \\
\hline Opel & 63 & Seat & 14 & Tazzari & 2 \\
\hline Fiat & 59 & Subaru & 14 & Vauxhall & 2 \\
\hline Honda & 55 & Dacia & 13 & Bugati & 1 \\
\hline Volkswagen & 51 & Kia & 10 & Daewoo & 1 \\
\hline BMW & 50 & Smart & 10 & Fisker & 1 \\
\hline Mitsubishi & 45 & Cadillac & 9 & Great Wall & 1 \\
\hline Land Rover & 42 & Aston Martin & 8 & Hummer & 1 \\
\hline Suzuki & 42 & Ferrari & 8 & Isuzu & 1 \\
\hline Jaguar & 41 & Bentley & 6 & MG & 1 \\
\hline Chevrolet & 34 & Infiniti & 6 & Pontiac & 1 \\
\hline Jeep & 33 & Saab & 5 & Recaro & 1 \\
\hline Audi & 25 & Alpina & 4 & Tata & 1 \\
\hline Porsche & 23 & Lotus & 4 & Veigel & (other) \\
\hline Mazda & 20 & Mini & & & 45 \\
\hline
\end{tabular}

The first five brands were: Renault, Mercedes, Peugeot, Citroën and Toyota. However, in the case of the first 20 brands, the number notifications exceeded the mean value and it was in total 1168 notifications. These brands have been taken into account in the cluster analysis using two-way joining. The results of this analysis were presented in the following figures, i.e.: year (Fig. 2), submitting country (Fig. 3), origin country (Fig. 4), risk type (Fig. 5) and entity taking measures (Fig. 6). 


\section{Bezpieczeństwo i ekologia}

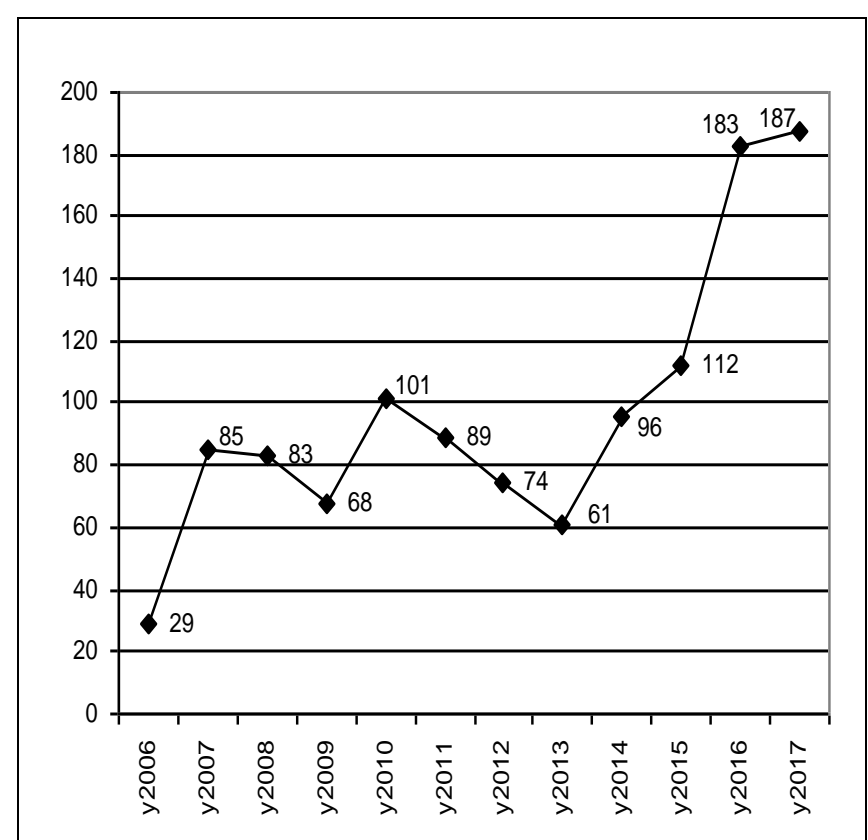

Fig. 1. The RAPEX notifications on passenger cars in particular years

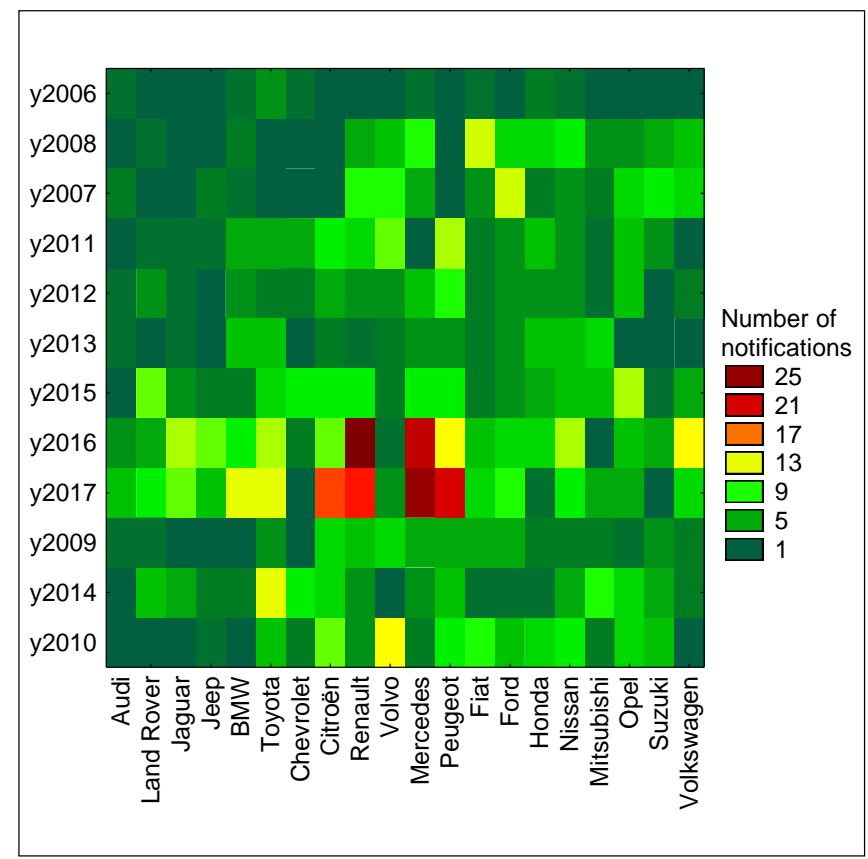

Fig. 2. Similarities of RAPEX notifications on passenger cars in brands and year

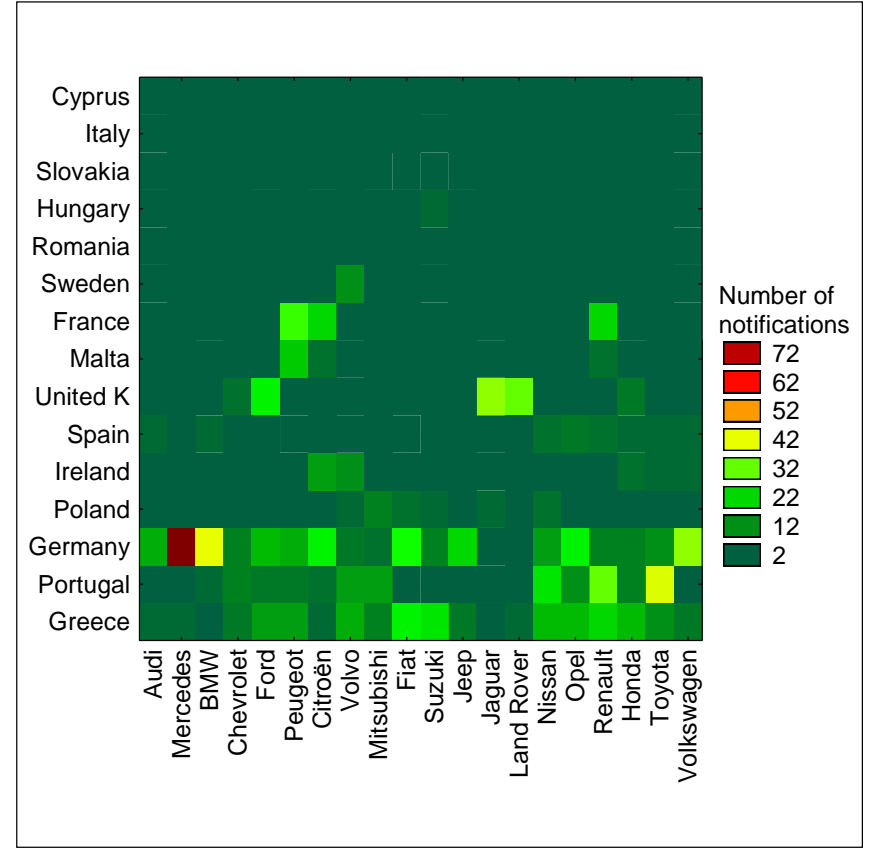

Fig. 3. Similarities of RAPEX notifications on passenger cars in brands and submitting country

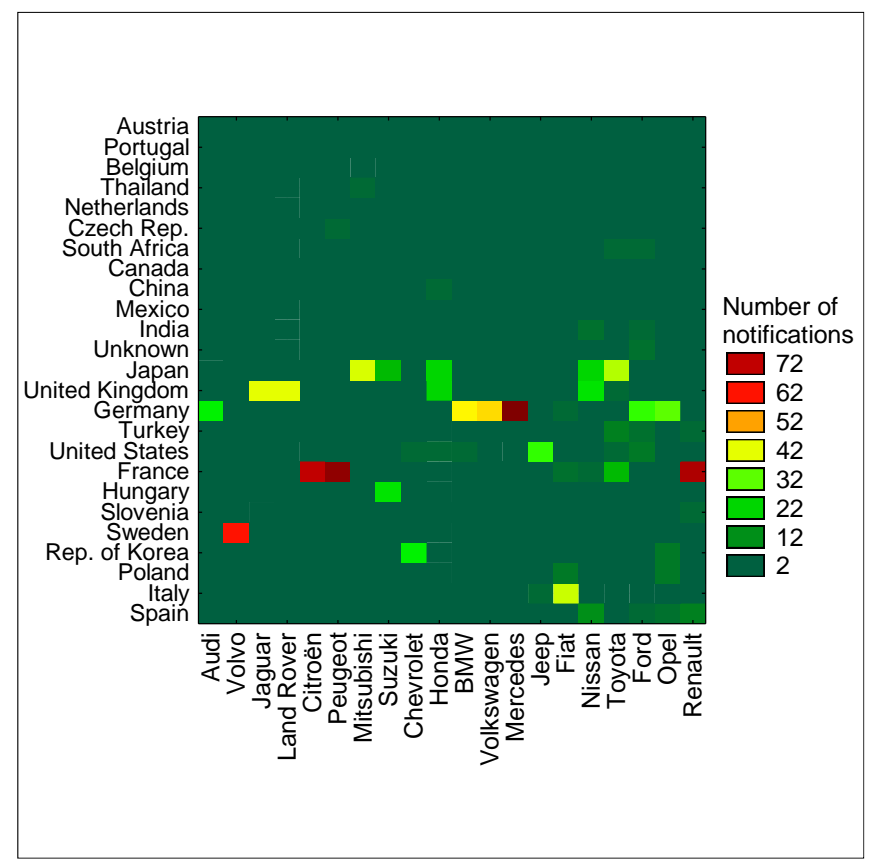

Fig. 4. Similarities of RAPEX notifications on passenger cars in brands and origin country 


\section{Bezpieczeństwo i ekologia}

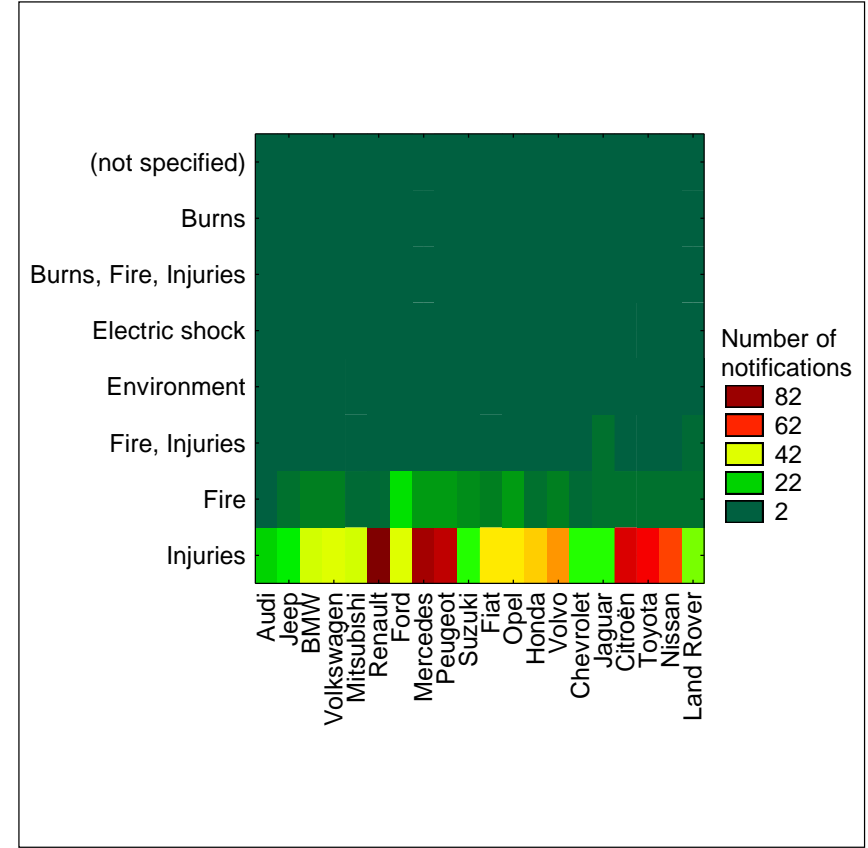

Fig. 5. Similarities of RAPEX notifications on passenger cars in brands and risk type

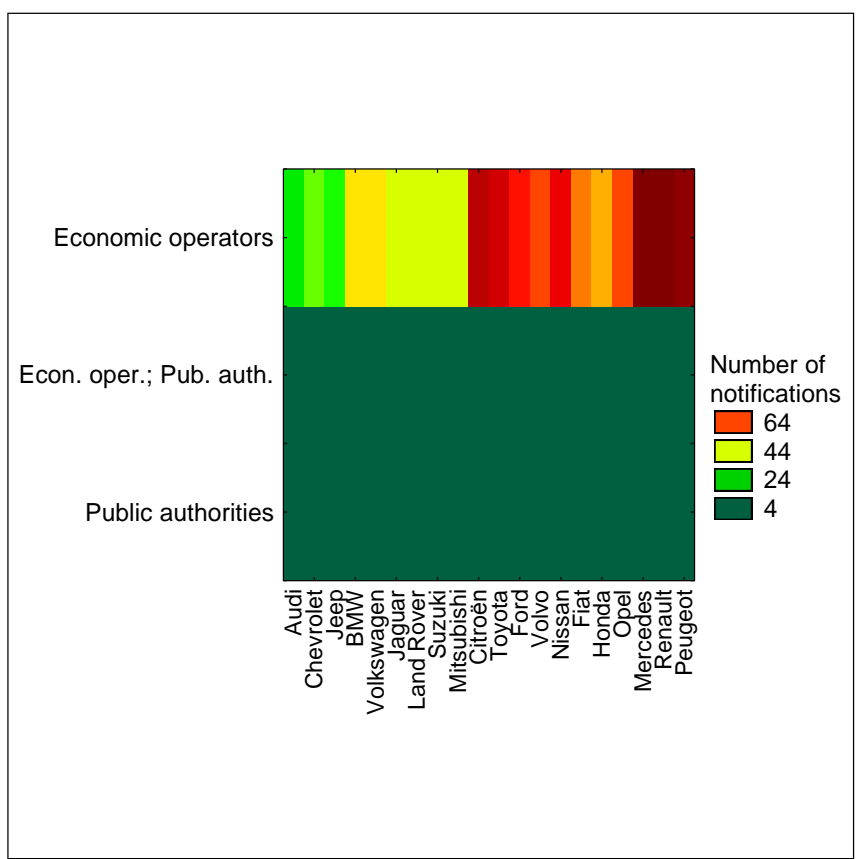

Fig. 6. Similarities of RAPEX notifications on passenger cars in brands and entity taking measures

The number of notifications generally increased from 2006 to 2010, then there was a downward trend until 2013, and again an upward trend until 2017 (Fig. 1). The mean value of notifications in 2006-2017 was 97 and it was exceeded in 2010 (101 notifications), 2015 (112), 2016 (183) and 2017 (187). The similar and the largest number of notifications in the examined period occurred in 2016 and concerned mainly Renault and Mercedes and in 2017 and concerned primarily Mercedes, Peugeot, Citroën, Renault (particular brands have been listed according to block colors, first brown, then dark red - Fig. 2). The annual reports indicated that the motor vehicles thanks to registration rules was product category with the highest number of reactions (feedback from national authorities on follow-up actions) [5, p. 4] after notifications among all product categories in 2014 [3, p. 26], 2015 [4, p. 17] and 2016 [5, p. 22].
The mean value of notifications within submitting country was 78 and this value was exceeded in case of notifications from Germany (392), Greece (225), Portugal (179) and United Kingdom (106). However, the cluster analysis indicated mainly notifications from Germany regarding Mercedes (Fig. 3), which allows to state that the manufacturer of this brand particularly cares about the user's safety.

Within the variable origin country the mean value was 47 and it was exceeded in case of notifications on cars from Germany (276), France (260), Japan (139), Sweden (62) and United States (56). The similarities in number of notifications could be noticed in case of Mercedes (from Germany) and Citroën, Peugeot, Renault (from France) (Fig. 4). However, particularly in the case of cars from Germany, a large number of notifications in the RAPEX may be indirectly related to a large number of cars produced in this country. The data obtained by The International Organization of Motor Vehicle Manufacturers (Organisation Internationale des Constructeurs d'Automobiles - OICA) indicate that Germany was the country with the greatest numbers of cars manufactured in 2015 and 2016 in Europe (about 6 million a year). The next countries in terms of the number of cars produced were: Spain (over 2 million), United Kingdom and France (about 1,5 million) and Czech Republic (over 1 million) [9].

The mean value in case of variable risk type was 146 notifications. Above this value were notifications related mainly to injuries (968) in already mentioned car brands: Renault, Mercedes, Peugeot, Citroën and also Toyota and Nissan. The annual RAPEX reports also indicated injuries as most frequently notified risk type $[4, p .18$; 5 , p. 23]. The other risk type with number of notifications above mean was fire (166) (Fig. 5).

The last examined variable was entity taking measures. These measures were taken mainly by economic operators (manufacturer, distributor or importer) -1159 notifications. This indicates that the economic operator feels responsible for the risks. The measure taken by the operator related to the same car brands as mentioned above, i.e.: Mercedes, Renault, Peugeot, Citroën also Toyota and Nissan (Fig. 6). The measure could refer mainly to recalling the cars from end users and carrying out voluntary corrective actions [1].

The example of cars that were recalled concerned Toyota. In case of this brand three separate recalls were made after notifications of unintended acceleration. These recalls related to floor mats, accelerator pedal and unrelated anti-block brake and concerned more than 9 millions cars worldwide in 2008-2011 [7, pp. 712, 713]. Wynn et al. noticed that in the European Union the RAPEX is recall notification system, which can be also used for cars [11, pp. 777, 778]. Winkle noted that tables from the RAPEX are used by the European Union and the German Federal Motor Transport Authority for analyzing and evaluating risks stemming from defects after market launch in view of necessity and urgency of product recalls $[10$, pp. 611,612].

\section{CONCLUSIONS}

The most frequently passenger car brands notified in the RAPEX were: Renault, Peugeot, Citroën (originated from France) and Mercedes (from Germany). The number of notifications significantly increased from about 30 in 2006 to about 180 in 2016 and 2017. Germany was the country, which notified passenger cars most commonly (it related mainly to Mercedes). The risk type, which was usually notified was injuries and also fire. The measures against the notified cars were most frequently taken by economic operator (manufacturer, distributor or importer). 
Information from the RAPEX are used in recall actions. This affects the maintenance and improvement of users' safety. In addition, it can also affect the image and self-discipline of manufacturers, because their data are published in this system.

More reliable results could be obtained by reference of number of notifications in the RAPEX to the number of registered cars of a given brand in the European Union. However, such data on brands would be difficult to obtain.

\section{REFERENCES}

1. European Commission, Rapid Alert System for dangerous nonfood products,

https://ec.europa.eu/consumers/consumers_safety/safety_prod ucts/rapex/alerts/, 31.01.2018

2. European Parliament, Council, Directive 2001/95/EC of the European Parliament and of the Council of 3 December 2001 on general product safety (Text with EEA relevance), OJ L 11, 15.1.2002, 4-17.

3. European Union, Keeping European Consumers safe. Rapid Alert System for dangerous non-food products 2014. Complete statistics, Publications Office of the European Union, Luxembourg 2015.

4. European Union, Rapid Alert System for dangerous products. 2015 results, Publications Office of the European Union, Luxembourg 2016.

5. European Union, Rapid Alert System for dangerous products. Working together to keep consumers safe. 2016 annual report, Publications Office of the European Union, Luxembourg 2017.

6. Klaschka U., Trust, but verify! Personal care products in the rapid alert system database RAPEX, "Sustainable Chemistry and Pharmacy" 2017, Volume 5, 30-41, DOI: 10.1016/j.jom.2011.06.007.

7. Marucheck A., Greis N., Mena C., Cai L., Product safety and security in the global supply chain: Issues, challenges and research opportunities, "Journal of Operations Management" 2011, Volume 29, Issues 7-8, 707-720, DOI: 10.1016/j.jom.2011.06.007.

8. Pose-Juan E., Fernández-Cruz T., Simal-Gándara J., State of the art on public risk assessment of combined human exposure to multiple chemical contaminants, "Trends in Food Science \& Technology" 2016, Volume 55, 11-28, DOI: 10.1016/j.tifs.2016.06.011.

9. The International Organization of Motor Vehicle Manufacturers (Organisation Internationale des Constructeurs d'Automobiles

\section{Bezpieczeństwo i ekologia}

- OICA), Word Motor Vehicle Production by country and type (production of passengers cars in 2015 and 2016), http://www.oica.net/category/production-statistics/2016statistics/, 2.02.2018.

10. Winkle T., Development and Approval of Automated Vehicles: Considerations of Technical, Legal, and Economic Risks, In: Maurer M., Gerdes J., Lenz B., Winner H. (eds), Autonomous Driving, Springer, Berlin, Heidelberg 2016, 589-618, DOI: 10.1007/978-3-662-48847-8_28.

11. Wynn M. T., Ouyang C., ter Hofstede A. H. M., Fidge C. J., Data and process requirements for product recall coordination, "Computers in Industry" 2011, Volume 62, Issue 7, 776-786, DOI: 10.1016/j.compind.2011.05.003.

\section{Samochody osobowe w notyfikacjach systemu RAPEX}

W artykule przedstawiono podobieństwa $w$ zakresie 1533 notyfikacji dotyczacych samochodów osobowych (podkategoria kategorii pojazdy silnikowe) w Systemie Szybkiego Powiadamiania o Niebezpiecznych Produktach Nieżywnościowych (RAPEX) w latach 2006-2017. W badaniach wzięto pod uwage marki samochodów osobowych oraz rok, kraj zgłaszajacy, kraj pochodzenia, typ ryzyka i podmiot podejmujacy środki. Zastosowano analizę skupień z wykorzystaniem metody grupowania obiektów $i$ cech $w$ programie Statistica 12. Najczęściej notyfikowane byly następujace marki: Renault, Peugeot Citroën (pochodzace z Francji) oraz Mercedes (z Niemiec). Ilość notyfikacji wzrosta od 2006 do 2017 roku. Samochody osobowe w systemie RAPEX byty najcześciej notyfikowane przez Niemcy (dotyczy to Mercedesa). Najczęściej zgłaszanym ryzykiem byly zranienia, a także ogień. Środki wobec notyfikowanych samochodów byly zwykle podejmowane przez operatora ekonomicznego (producenta, dystrybutora lub importera).

Author:

dr inż. Marcin Pigłowski - Gdynia Maritime University, Faculty of Entrepreneurship and Quality Science, Department of Commodity and Quality Management, m.piglowski@wpit.am.gdynia.pl

JEL: L62 DOI: 10.24136/atest.2018.063

Data zgłoszenia: 2018.05.21 Data akceptacji: 2018.06.15 